\title{
Resilience, Post-Traumatic Growth, and Psychological Well-Being Among Adolescents Experiencing Parents' Marital Dissolution
}

\author{
Daniswara Agusta Wijaya ${ }^{1}$ Endang Widyorini', Emiliana Primasturi, \\ Jemerson Dominguez $z^{4}$ \\ 1,2,3Fakultas Psikologi, Universitas Katolik Soegijapranata; \\ ${ }^{4}$ Psychology Department, De La Salle University, Philippines \\ e-mail: ${ }^{* 1}$ daniswaragusta@gmail.com
}

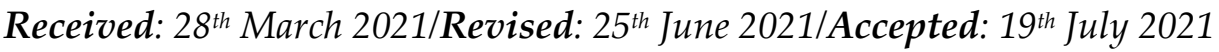

\begin{abstract}
The marital dissolution as a traumatic event for children and adolescents might yield different outcomes for each adolescent. Previous studies suggested that adolescents who have high resilience tend to experience positive changes / posttraumatic growth following traumatic events, which results in higher well-being. Hence, it is necessary to conduct research about resilience and post-traumatic growth as predictors of psychological well-being among adolescents who have been through their parents' marital dissolution. The recent study aims to investigate the relations among those variables. A total of 56 participants (mean age: $15.27 ; 66.1 \%$ female) who lived in Semarang completed three measurements. Correlational, t-test, and path analysis were applied. The result suggests that both resilience and post-traumatic growth significantly and positively correlated toward psychological well-being. Furthermore, post-traumatic growth was found to have a significant partial mediating effect on the relationship between resilience and psychological well-being. These findings suggest that though promoting resilience could improve the psychological well-being of adolescents who have been through their parents' marital dissolution, clinicians need to ensure that adolescents experience post-traumatic growth through cognitive therapy or counseling sessions to achieve better psychological well-being.
\end{abstract}

Keywords: resilience, post-traumatic growth, psychological well-being, marital dissolution, adolescent

Abstrak. Perceraian merupakan sebuah peristiwa traumatis bagi anak dan remaja yang dapat
menimbulkan luaran yang berbeda bagi tiap individu. Penelitian sebelumnya menggambarkan
bahwa remaja dengan resiliensi tinggi dan mengalami pertumbuhan positif atau post-traumatic
growth pasca peristiwa traumatis, menunjukkan well-being yang lebih baik. Maka, penting
untuk diteliti bagaimana hubungan resiliensi dan post-traumatic growth menjadi prediktor
terhadap psychological well-being pada remaja korban perceraian orangtua. Tujuan penelitian
ini adalah menyelidiki hubungan ketiga variabel tersebut. 56 partisipan (rerata usia: 15,27;
$66,1 \%$ perempuan) yang tinggal di Semarang mengisi tiga alat ukur. Analisis korelasional, t-
test dan analisis jalur digunakan. Temuan menunjukkan bahwa resiliensi dan post-traumatic
growth memiliki hubungan positif dan signifikan terhadap psychological well-being. Selain itu,
post-traumatic growth juga ditemukan memiliki efek mediasi parsial yang signifikan pada
hubungan antara resiliensi dan psychological well-being. Temuan-temuan dalam artikel ini 


\section{WIJAYA, WIDYORINI, PRIMASTURI, \& DOMINGUEZ}

menunjukkan bahwa peningkatan resiliensi akan membantu remaja dalam meningkatkan psychological well-being pasca perceraian orangtua, namun profesional juga perlu memastikan bahwa remaja mengalami post-traumatic growth melalui terapi kognitif maupun sesi konseling untuk mencapai tingkat psychological well-being yang lebih baik.

Kata kunci: resiliensi, post-traumatic growth, psychological well-being, perceraian, remaja

Based on the last updated data on 28 August 2020 (Yusuf, 2020), the number of marital dissolution or divorce cases, which results in children living with single parents and dealing with parent's conflict or even with the law, keep increasing these days. According to the Indonesia Central Bureau of Statistics (known as Badan Pusat Statistik Indonesia), the number of cases in Central Java was reported to be the highest with about 65,755 cases, followed by East Java $(61,870$ cases) and West Java $(37,503)$ (Rizaty, 2021). Furthermore, Muhammad Camuda, the Vice Chairman of the Religious Court Class 1A Semarang stated that more than 100 new divorce or marital dissolution cases were submitted each day in Semarang during the pandemic ("Perceraian Di Semarang Naik 3 Kali Lipat Selama Wabah Corona," 2020). Step aside from the pandemic issues, the number of marital dissolution cases has increased each year since 2015. Based on the statistical report from the Religious Court (Andini, 2019), marital dissolution in 2018 was around 408,202 cases. Those data show remarkable rising cases of marital dissolution along with the consequences toward many aspects of the family.

For these past recent years, a large number of studies and literature on marital dissolution have been published as a concern of its consequences on physical and mental health (Amato, 2014). Recent General Guidance of Child Protection by the Ministry of Women and Child Protection stated that children with the risk of having single parents due to mortality or marital dissolution are included on the list of issues that should obtain support and concern (Pedoman Umum Perlindungan Anak Penanganan COVID-19, 2020). Marital dissolution is defined as a state in which marriage is formally and legally terminated by the court or widely known as divorce (Braver \& Lamb, 2013). In general, Amato (2014) explained that the process of divorce in marriage does not only bring consequences for the adults or the couple themselves but also the children as an inseparable part of the marriage. Hornor (2015) once also asserted in terms of 
Adverse Childhood Experiences, marital dissolution is one of the traumatic event exposures which cause a crisis for children along with physical violence, verbal assault, neglect, domestic violence, drug abuse, and domestic criminal behavior.

Recently, Santrock (2011) stated that there was growing evidence on how adolescents from divorced families demonstrated a lower level of adaptability compared to typical adolescents. Besides, previous research suggested that some of these adolescents show problems regarding their well-being, specifically psychological well-being (Potter, 2010; Ramadhani et al., 2016; S Pappa, 2013). Psychological wellbeing was first introduced by Ryff $(1989,2014)$ based on eudaimonia which is a philosophy constructed by Aristotle. Thus, the construct of psychological well-being argues that the experience of feeling expressiveness as a result of engaging in actions consistent with one's daimon or true potential and pursuit of intrinsic goals (Hefferon \& Boniwell, 2011; Ryff, 2014; Waterman et al., 2010).

Ryff then proposed a model in distilling components of optimal human functioning and built each component based on multiple underlying theoretical constructs (Ryff, 2017). Ryff's model of psychological well-being (Ryff, 2014) consists of six aspects including: 1) autonomy, which refers to characteristics of having clear life goals and self-confidence, being resistant to social demands, regulating behavior from within and evaluating self from personal standards; 2) environmental mastery, shown by having control on environment, making effective use of opportunities, and being able to choose or create context for personal values and needs; 3) personal growth, described as willing to have continuous improvement, having openness to new opportunities, realizing self-potential, evaluating changes and progress; 4) positive relation with others, shown by concern about the welfare of others; showing strong empathy, affection and intimacy; understanding give and take in human relationships; 5) purpose in life, defined as having goals and sense of directness, being able to feel a meaning of life, holding beliefs that give life purpose; and 6) life acceptance, characterized by positive attitude toward self, realizing and accepting multiple aspects of self, and feeling positive about past life. 


\section{WIJAYA, WIDYORINI, PRIMASTURI, \& DOMINGUEZ}

Considering the complexity of psychological well-being rather than merely having a positive affect and sense of satisfaction, it is necessary to research factors predicting psychological well-being in adolescents in regards to the family context as suggested in the previous article (Savitri \& Listiyandini, 2017). Some evidence from the previous studies showed that individuals experiencing parents' marital dissolution demonstrated a lower level of psychological well-being. However, Santrock (2011) reported that the majority of adolescents can overcome negative emotions and face those hard times; thus, they are relatively competent to handle the condition and improve in positive functioning. A recent study from Harding et al. (2019) proposed internal and external resource protective factors of psychological well-being in the face of a stressor. The external factor is social support from family, friends, and significant others while internal factors consist of resilience, self-efficacy, and mindfulness.

Resilience is defined as one's personal qualities that enable an individual to thrive when facing adversity in life (Connor \& Davidson, 2003). In addition, Richardson (2002), in his metatheory article, defined resilience using innate resilience which refers to motivational forces within individuals and groups that are activated by specific experiences and drive them toward resiliently reintegrated from disruption. In this study, the aspect of resilience consists of personal competence, high standards, and tenacity; trust in one's instincts, tolerance of negative affect and strengthening effects of stress; positive acceptance of change and secure relationships; control; and spiritual influences (Connor \& Davidson, 2003).

Although resilience might predict psychological well-being in adolescents experiencing parents' marital dissolution, in more detail, Harding et al. (2019) also mentioned that resilience promotes psychological well-being by facilitating people to experience growth after stressful life events. Supporting that finding, Ryff (2014) and Harrington \& Loffredo (2010) proposed changes in life, rumination, and insight which are part of the post-traumatic growth process also contribute to promoting psychological well-being. Therefore, it is important to prove whether the effect of resilience on psychological well-being will be greater if it is done directly or indirectly, through intermediaries of post-traumatic growth as a mediating variable. 
Post Traumatic Growth is a multi-defined terminology since it is a result of the development of a previous construct known as stress-related growth that is still discussed recently (Hefferon \& Boniwell, 2011). For example, after the hurricane and war, some researchers reported that survivors demonstrate changes such as having more faith in God, having better relations with friends and family, and having a better understanding of how people might be so helpful (Meyerson et al., 2011; Ruini et al., 2013). Tedeschi \& Calhoun (2004) proposed post-traumatic growth as a more relevant term concerning the outcomes observed among the survivors of traumatic events instead of the initial theory of stress-related growth. Calhoun and Tedeschi in the Handbook of Posttraumatic Growth Research and Practice defined post-traumatic growth as a positive change following the traumatic event(s) exposure as a result of the struggle with difficulties (Calhoun \& Tedeschi, 2006).

Calhoun \& Tedeschi (2006) divided post-traumatic growth into five aspects: personal strength, appreciation of life, relating to others, new possibilities, and spiritual change. In detail, Calhoun \& Tedeschi (2006) elaborated those aspects as follows: 1) personal strength defined as, a stage when trauma survivors report positive changes and describe themselves as a "better version"; 2) relating to others, refers to the development of closer relationships with family and friends. 3) appreciation for life, including changes in which individuals increase existential awareness; 4) new possibilities, which explains individuals' desire to change life goals and gain new skills; 5) spiritual changes, refer to changes in participation in religious activity and have belief in higher-being as well.

Tedeschi \& Calhoun (2004) proposed that one's ability to manage distressing emotions through crisis facilitates people to alter cognitive processing toward posttraumatic growth. The quality to manage distressing emotions possessed by an individual in the face of difficulties is widely known as resilience (Connor \& Davidson, 2003). Additionally, a study from Mahdi et al. (2014) suggested there are two factors of resilience that significantly correlated with post-traumatic growth, which are adaptive capacity and positive acceptance. 


\section{WIJAYA, WIDYORINI, PRIMASTURI, \& DOMINGUEZ}

Although some theories have elaborated the relations among the variables, the mediating effects of post-traumatic growth in the relations between resilience and psychological well-being have not been well established yet. Nevertheless, some recent studies on traumatic exposure-related topics suggest that resilience will predict psychological well being through the certain process such as the finding of meaning in life (Du et al., 2017), attaining new cognitive strategies, and engaging in positive growth after a crisis (Brooks et al., 2015) explained in the current model of PostTraumatic Growth by Calhoun et al. (2012). Results of previous studies suggest the possible mediating variable between the relations of resilience and psychological wellbeing which refers to positive growth following a traumatic events-related crisis.

Current updated model of post-traumatic growth proposed by Calhoun et al. (2012) explained that certain individual traits and modality strongly predicts the level of post-traumatic growth following the traumatic crisis. Individuals would develop intrusive rumination thoughts as a reaction to trauma exposure. Then, people typically have to engage with certain strategies to manage overwhelming emotions caused by distress (Calhoun \& Tedeschi, 2006). This stage is in which resilience takes a role to help individuals continue living after hardship. As people try to manage distress caused by the crisis, intense cognitive processing of the difficult circumstances also occurs. Those cognitive processing enhance new understanding of the assumptive world since the previous ones have shattered from the traumatic events (Tedeschi \& Calhoun, 1996). Post-traumatic growth is connected with the development of this new assumptive word manifested as personal strength, appreciation to life, relating to others, new possibilities, and spiritual change. Furthermore, through experiencing post-traumatic growth individuals tend to develop new wisdom which eventually leads to psychological well-being (Calhoun et al., 2012; Ryff, 2014; Tedeschi \& Calhoun, 2004). Supporting the assumption of mediating effects of post-traumatic growth in the relationship between resilience and psychological well-being, a previous study by O'Rourke et al. (2008) also stated that post-traumatic growth, in turn, will facilitate individuals in meaning-making and performing higher functioning in life following the exposure of the traumatic event. 
Regarding marital dissolution as specific childhood traumatic event, Schaan et al. (2019) stated that marital dissolution become a developmental challenge for many children to cope with. Furthermore, Schaan et al. (2019) illustrated that children and adolescents coming from divorced families might face less parental care, more emotional and physical abuse, more emotional neglect, more loneliness, chronic stress, attachment avoidance, and anxiety. As a consequence, children in the development process to young adults (including adolescence) might experience reduced well-being, resilience, and increased levels of childhood trauma and rejection sensitivity, caused by psychological maladjustment and biological stress response system (in hypothalamicpituitary-adrenocortical axis and the sympathetic nervous system) (Davidson et al., 2014). As mentioned earlier, resilience plays an important role in the healing process from the traumatic experience. Hornor (2015) explained that resilience helps children to develop more efficient coping strategies in overcoming trauma to attain a higher level of functioning manifested in psychological well-being.

In addition, the process toward psychological well-being in the face of crisis after the traumatic event is influenced by many factors such as insight, rumination, and self-reflection, besides resilience as suggested by Harrington \& Loffredo (2010). In line with those findings, rumination and cognitive processes which produce insight and self-reflection are also found in the integrated model of the post-traumatic growth process which in turn result in higher psychological well-being (Tedeschi \& Calhoun, 2004). Hence, it is necessary to investigate the role of resilience and post-traumatic growth toward psychological well-being following the crisis of a traumatic event exposure which is marital dissolution specifically in this research. Besides, since the experience of post-traumatic growth is expected higher in adolescents to young adults, this study could capture the clear relationship between resilience, post-traumatic growth, and psychological well-being as an initial evidence-based finding.

The recent study aimed to investigate the relations among resilience, posttraumatic growth, and psychological well-being of adolescents experiencing parents' marital dissolution. Post-traumatic growth in this research had a role as a mediating variable, expected to deliver the effects of the independent variable to the dependent 


\section{WIJAYA, WIDYORINI, PRIMASTURI, \& DOMINGUEZ}

variable. The hypothesis proposed in this study was that resilience had a positive effect on psychological well-being in adolescents experiencing parents' marital dissolution mediated by post-traumatic growth. Thus, this study proposed that resilience would positively predict post-traumatic growth, and post-traumatic growth will positively influence psychological well-being.

\section{Figure 1.}

Research Analysis Design

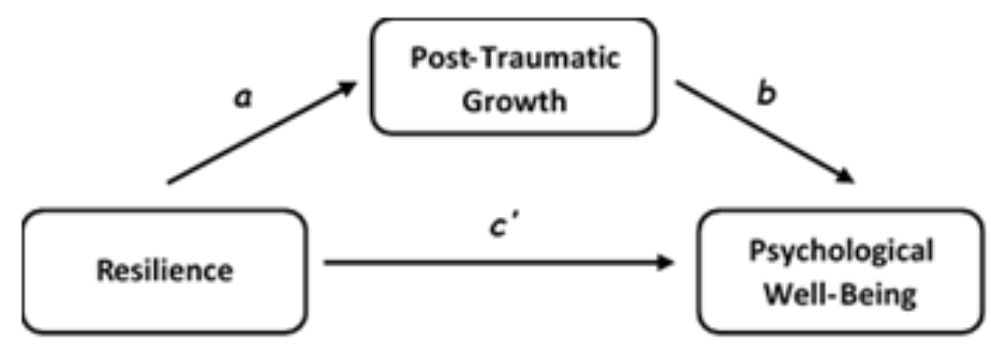

\section{Methods}

\section{Research Participants}

Convenience sampling was used in this research, and a total of 56 participants (mean age: $15.27 ; 66.1 \%$ female) completed measurements in this study. For the research purpose, individuals who participated in this study were categorized based on their age between 12 to 18 years old, in early and middle adolescence (Monks et al., 2014), and live in Semarang. The author set framing criteria in which the respondents should be adolescents whose parents have been through marital dissolution or divorce.

\section{Research Instruments}

This study used three types of scales to measure each psychological variable. Resilience as the independent variable in this study was measured with CD-RISC (Connor \& Davidson, 2003). CD-RISC used in this study was translated into Indonesian language and statistically analyzed. Statistical analysis results showed that this instrument was valid (Pearson's product moment $\mathrm{r}=.35-.81 ; \mathrm{p}=.000-.005$ ) and reliable (Cronbach's alpha $\alpha=.929)$ CD-RISC Indonesia language version had 25 items scale, which each item was rated on a 5-points scale from 0 (not true at all) to 4 (true 
nearly all the time). This scale measured resilience based on some characteristics presented in resilient individuals such as personal competence, high standards, and tenacity; trust in one's instincts, tolerance of negative affect and strengthening effects of stress; positive acceptance of change and secure relationships; control; and spiritual influences. Some items in this scale were: "I am able to adapt to change", "When things look hopeless, I don't give up", and "I am in control of my life".

The mediating variable which was post-traumatic growth was measured using Post-Traumatic Growth Inventory (Andrykowski et al., 2015; Tedeschi \& Calhoun, 1996). The original version of PTGI was translated into the Indonesian language for this research. The statistical analysis results showed that 21 items in this instrument were all valid (Pearson's product moment $\mathrm{r}=.49-.80 ; \mathrm{p}=.000$ ), and this scale was reliable (Cronbach's alpha $\alpha=$.938). These 21 scale items were a six-point scale from 0 (I did not experience this change as a result of my crisis) to 5 (I experienced this change to a very great degree as a result of my crisis). Several aspects were measured to investigate the level of post-traumatic growth experienced by each participant as follows: personal strength, appreciation to life, relating to others, new possibilities and spiritual change. Some examples of this scale's items are "I developed new interests", "I have a greater sense of closeness with others", and "I am able to do better things in life".

Psychological well-being in this study as a dependent variable was measured using psychological well-being scale modified in the Indonesian language version. The original version consisted of 18 items scale with 7 points scale from 1 (strongly agree) to 7 (strongly disagree), created by Ryff et al. (2017). The statistical analysis results showed that only 13 items in Bahasa Indonesia version of this instrument were valid (Pearson's product-moment $\mathrm{r}=.30-.71 ; \mathrm{p}=.000-.023$ ), and this final 13-items scale was reliable (Cronbach's alpha $\alpha=.774$ ). Six aspects of psychological well-being proposed by Ryff were measured by this instrument including autonomy, environmental mastery, personal growth, positive relation with others, purpose in life and life acceptance. There was a total of 13 items that were valid such as, "I like most parts of my personality", "I am good at managing the responsibilities of daily life", "I tend to be influenced by people with strong opinions". 


\section{WIJAYA, WIDYORINI, PRIMASTURI, \& DOMINGUEZ}

\section{Research Procedure}

This research was approved by the Research Ethics Commissions of Psychology Faculty Soegijapranata Catholic University. Data collection was conducted for approximately three months from January 2021 to March 2021. Questionnaires were distributed using Google Form to recruit participants.

\section{Data Analysis}

Research data in this study were then analyzed using mediation analysis with the help of IBM SPSS Statistics 26. PROCESS Macro-version 2.13 or also widely known as conditional process analysis was used specifically for hypothetical testing. PROCESS used least-square regression-based path analysis which is commonly used in mediation analysis (Hayes \& Rockwood, 2017). This study was analyzed with a 95\% confidence interval (CI) and 5000 bootstraps.

\section{Results}

\section{Preliminary Analysis}

Assumption tests were conducted as the first stage of data analysis. Normality using the Kolmogorov Smirnoff test indicated that all variables followed a normal distribution $(p>.05)$. Furthermore, there were also linear relations between resilience with post-traumatic growth (deviation from linearity $=1.78 ; \mathrm{p}=.081$ ), post-traumatic growth with psychological well-being (deviation from linearity $=1.51 ; p=.157$ ) and resilience with psychological well-being (deviation from linearity $=1.43 ; \mathrm{p}=.193$ ).

\section{Table 1}

Demographic Data

\begin{tabular}{llc}
\hline Variable & Category & Percentage \\
\hline Gender & Male & 33.9 \\
& Female & 66.1 \\
\hline Educational Level & Junior High School (SMP) & 50.0 \\
& Senior High School (SMA/K) & 39.3 \\
& University & 10.7 \\
\hline Living together with & Biological Father & 8.9 \\
& Biological Mother & 58.9 \\
& Blended Family & 19.6 \\
& Others & 12.5 \\
\hline
\end{tabular}


Table 1 shows the demographical data of participants who completed measures ( $\mathrm{N}=56 ; 66.1 \%$ female). Based on age, adolescents in this research ranged from 12 to 18 years old $($ mean $=15.27$; standard deviation $($ S.D. $)=2.03)$. The respondents were mostly in Junior High School $(\mathrm{N}=28 ; 50 \%)$. In addition, the duration since parents' marital dissolution varied from less than a year to 16 years $($ mean $=8.18$; S.D. $=3.634)$. Currently, 5 (8.9\%) were living with biological father only, 33 (58.9\%) were living with biological mother only, $11(19.6 \%)$ were living with blended family as one of their parents was engaged in a new marriage, $7(12.5 \%)$ were living with their grandparents or relatives.

\section{Associations of Study Variables}

Correlation analyses were conducted to assess possible associations between age, educational level, and duration of marital dissolution with three main variables (resilience, PTG, and PWB). None of those three was correlated with the main variables (all $\mathrm{p}>.05)$. A t-test was also conducted in this study to investigate any difference in main variables concerning sex groups, it was found that the difference between sex groups was only presented in post-traumatic growth $(t=2.08 ; p=.042)$.

Results of Pearson correlations are shown in Table 2. Data analysis showed that there was a significant positive correlation not only between resilience and posttraumatic growth $(\mathrm{r}=.66)$ but also between resilience and psychological well-being $(\mathrm{r}=$ .78). Furthermore, there were significant relationships between post-traumatic growth and psychological well-being $(\mathrm{r}=.68)$. These findings suggested that PWB was positively associated with resilience and post-traumatic growth. Results concerning means, S.D., and correlations for all measures are shown in Table 2.

Table 2.

Means, Standard Deviations and Correlations

\begin{tabular}{|c|c|c|c|c|c|}
\hline Variable & Mean & SD & RS & PTG & PWB \\
\hline RS & 68.25 & 15.94 & & & \\
\hline PTG & 67.17 & 19.74 & $.663^{* *}$ & & \\
\hline PWB & 66.14 & 10.53 & $.779 * *$ & $.684^{* *}$ & \\
\hline
\end{tabular}




\section{WIJAYA, WIDYORINI, PRIMASTURI, \& DOMINGUEZ}

\section{Path Analysis and Mediating Role of PTG}

Test of mediation (model 4) from PROCESS Macro-version 2.13 was performed to examine whether post-traumatic growth was a mediator of the relationship between resilience and psychological well-being (Hayes \& Rockwood, 2017). Table 3 summarizes the path analysis results. The result showed that in path a, resilience significantly predicted post-traumatic growth $(\beta=.684 ; \mathrm{LLCI}=.473 ; \mathrm{ULCI}=.894)$. Path $b$ which explained the effect of post-traumatic growth on psychological well-being showed that the link was significant $(\beta=.178 ; \mathrm{LLCI}=.050 ; \mathrm{ULCI}=.306)$. Direct effect of resilience toward psychological well-being shown as coefficient $c^{\prime}$ was presented to be significant $(\beta=.356 ; \mathrm{LLCI}=.224 ; \mathrm{ULCI}=.488)$ although it was lower than the total effect $(\beta=.477 ; \mathrm{LLCI}=.372 ; \mathrm{ULCI}=.582)$. Moreover, the result also indicates that there was a significant indirect effect of resilience to psychological well-being through posttraumatic growth $(\beta=.121 ; \mathrm{LLCI}=.047 ; \mathrm{ULCI}=.232)$. Thus, post-traumatic growth partially mediated the relationship between resilience and psychological well-being.

\section{Table 3.}

Path Analysis

\begin{tabular}{lllllllll}
\hline & $\mathrm{B}$ & $\mathrm{SE}$ & $\mathrm{t}$ & $p$ & $\mathrm{R}^{2}$ & $\mathrm{~F}(d f)$ & LLCI & ULCI \\
\hline $\mathrm{a}$ & .684 & .105 & 6.513 & .000 & .440 & $\mathrm{~F}(1)=42.420$ & .473 & .894 \\
\hline $\mathrm{b}$ & .178 & .064 & 2.783 & .007 & .657 & $\mathrm{~F}(2)=50.834$ & .050 & .306 \\
\hline $\mathrm{c}^{\prime}$ & .356 & .066 & 5.407 & .000 & - & - & .224 & .488 \\
\hline Total Effect & .477 & .052 & 9.137 & .000 & - & - & .372 & .582 \\
\hline Indirect Effect & .121 & .048 & - & - & - & - & .047 & .232 \\
\hline
\end{tabular}

Note: $\mathrm{a}=\mathrm{RS} \rightarrow \mathrm{PTG} ; \mathrm{b}=\mathrm{PTG} \rightarrow \mathrm{PWB} ; \mathrm{c}^{\prime}=\mathrm{RS} \rightarrow \mathrm{PWB}$

Figure 2.

Path Analysis Result

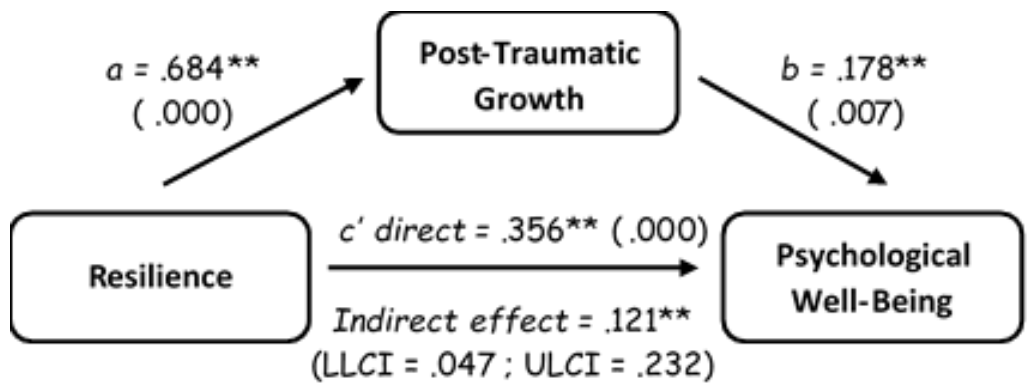




\section{Discussion}

Based on the demographic data, there was no observed correlation between demographic variables and three main variables. Yet, it was found that there is a difference only in post-traumatic growth for gender (male and female). Females were reported to experience higher post-traumatic growth compared to males. This finding is in line with the meta-analysis by Vishnevsky et al. (2010) which reported that women showed more post-traumatic growth than men though not statistically significant. Females are known to be more engaged with ruminative thoughts and to utilize emotional coping styles, which in the post-traumatic framework, precipitate the cognitive and behavioral strategies to attain emotional stability after trauma (Calhoun et al., 2012; Hu et al., 2017; Vishnevsky et al., 2010). As post-traumatic growth is a result of struggling after trauma, that reason might be the best to explain higher posttraumatic growth among females. While post-traumatic growth showed gender differences, resilience and psychological well-being did not show any significance. No significant difference in resilience and psychological well-being supported the findings in previous studies among adolescents (Sun \& Stewart, 2007; Visani et al., 2011).

This research aimed to investigate the role of post-traumatic growth in the relationship between resilience and psychological well-being among adolescents experiencing parents' marital dissolution. Table 3 reflects the association between the three main variables of the current article. A strong and significant positive relationship was found between resilience and psychological well-being. Similar to findings in previous research (Leme et al., 2015) which explained that resilience helps adolescents cope with parent's marital dissolution, this condition resulted in a higher level of psychological well-being in turn.

In addition, a significant positive correlation was observed in the relations between resilience and post-traumatic growth. The previous study regarding traumatic events or adversity Dekel et al. (2011) found that their systematic review is in line with this article result. This result, withal, is in contrast with the previous article (Greup et al., 2018) conducted among illness-specific stressors, it reflected negative relations 
between the ability to endure stress and post-traumatic growth. Even so, the current finding gives us a clearer picture of relations between these two variables for the family-specific issue, as mentioned by Kira et al., (2012), that different traumatic events cause different effects on adolescents.

A similar pattern was also observed between post-traumatic growth and psychological well-being in which both variables were significantly correlated. This finding demonstrated a similar image with previous studies on adults that suggested positive growth following traumatic events was positively associated with psychological well-being (Boerner et al., 2017; Ruini et al., 2013; Tavernier \& Willoughby, 2012). This result also gives new evidence of the theoretical frameworks proposed by Calhoun et al. (2012). The existed framework mentioned that posttraumatic growth will facilitate individuals in developing new wisdom, which is strongly reflected in a new narrative that recognizes the complexity of this world than general happiness. Thus, by developing new wisdom, people will eventually attain higher well-being (Calhoun et al., 2012).

Furthermore, the findings of the current study evidently support the idea of the literature review that resilience and post-traumatic growth both predict the level of psychological well-being specifically. That said, post-traumatic growth plays a partial mediation account in the current research framework. Partial mediation refers to the condition that both resilience and post-traumatic growth could predict psychological well-being; however, the outcomes will increase if adolescents are able to experience post-traumatic growth. Supporting this finding, the article from Leme et al. (2015) explained that resilience helps adolescents to cope with traumatic events especially marital dissolution through a period of time which means there are positive changes that result in a higher level of psychological well-being. Additionally, some other studies also help to explain this phenomenon that higher level of well-being in adolescents achieved when individuals could go through their intrusive thought and express better appreciation toward life, which are parts of the process that happened in post-traumatic growth (Park et al., 2010; Tavernier \& Willoughby, 2012). This result is in line with the current model of post-traumatic growth which illustrates each stage 
from rumination to narrative of new wisdom affects well-being (Calhoun et al., 2012; Calhoun \& Tedeschi, 2006). In summary, with respect to the model, resilience as a modality that helps individuals could predict the level of psychological well-being directly since it also contributes to the whole process of growth. Nevertheless, the whole following stages of post-traumatic growth would be able to predict the level of well-being better than resilience as a single attribute and growth is more likely to enhance psychological well being which is more complex than simple measures of general happiness (Calhoun et al., 2012).

In conclusion, as this study finding presented, resilience could predict the level of psychological well-being directly. Even so, the effects of resilience on psychological well-being will increase through post-traumatic growth as mediating variable. These findings clearly support the idea of resilience helps children to develop more efficient coping strategies in the process toward higher psychological well-being after overcoming trauma caused by certain marital dissolution-related adversity such as less parental care, more emotional and physical abuse, more emotional neglect, more loneliness, chronic stress, and attachment avoidance and anxiety (Hornor, 2015; Schaan et al., 2019). As adolescents with a high level of resilience are able to adopt effective coping strategies, it will facilitate post-traumatic growth through insight, rumination and self-reflection which would result in a higher level of psychological well-being and reduce the negative consequences following the marital dissolution of their parents (Davidson et al., 2014; Harrington \& Loffredo, 2010; Tedeschi \& Calhoun, 2004).

There are several limitations in the current work which should be considered for future research. First, the current sample was relatively small and the results were based on only adolescents who live in Semarang. The result of this study needs to be replicated and verified in other populations. Second, the development of posttraumatic growth needs time. Therefore, a cross-sectional study cannot precisely demonstrate the dynamic process. Future studies can manage a longitudinal design to examine the dynamic development of relationships between resilience, post-traumatic growth, and psychological well-being. Last, future research should also consider using more than a single method to obtain better and more comprehensive data, for example 


\section{WIJAYA, WIDYORINI, PRIMASTURI, \& DOMINGUEZ}

combining scales and interviews as a data collection method. Despite some limitations, this initial research adds a new framework in the family-specific traumatic events exposure. Further research is required to help in the provision of integrated knowledge.

\section{Conclusion}

This study aimed to understand the role of post-traumatic growth as a mediator for the relationship between resilience and psychological well-being among adolescents experiencing parents' marital dissolution. Results reflected that posttraumatic growth plays a partial mediating role in the relations between resilience and psychological well-being. This article supports the idea that resilience can contribute to psychological well-being directly. Still, higher psychological well-being will be attained when individuals work their resilience to experience larger post-traumatic growth.

\section{Suggestions}

This study also gives the idea that a practitioner could help adolescents lessen the negative consequences of parents' marital dissolution on the level of psychological well-being specifically. There are two main points that this research finding hinted at. First, by promoting the resilience of children and adolescents, we could help them deal with stressors and thrive to grow despite adversity in life. Second, to attain better psychological well-being following parents' marital dissolution, guidance or counseling or therapy should be focused to enhance positive changes and growth that might happen in the process of recovery. Cognitive Behavioral Therapy or Counseling should be implemented in many settings, such as educational and clinical ones, as mentioned that utilizing cognitive and behavioral processes helps individuals overcome negative impacts of trauma and enhance positive growth (Calhoun et al., 2012; Tedeschi \& Calhoun, 2004).

\section{References}

Amato, P. R. (2014). The Consequences of Divorce for Adults and Children: An Update. Drustvena Istrazivanja, 23(1), 5-24. https://doi.org/10.5559/di.23.1.01

Andini, A. (2019). Pertengkaran dan masalah ekonomi: penyebab utama perceraian. Lokadata. $\quad$ https://lokadata.id/artikel/tingkat-perceraian-lebih-tinggi-dari- 
perkawinan

Andrykowski, M. A., Steffens, R. F., Bush, H. M., \& Tucker, T. C. (2015). Lung Cancer Diagnosis and Treatment as a Traumatic Stressor in DSM-IV and DSM-5: Prevalence and Relationship to Mental Health Outcomes. Journal of Traumatic Stress, 28(3), 206-213. https://doi.org/10.1002/jts.22005

Boerner, M., Joseph, S., \& Murphy, D. (2017). Reports of Post-Traumatic Growth and Well-Being: Moderating Effect of Defense Style. Journal of Social and Clinical Psychology, 36(9), 723-737. https://doi.org/10.1521/jscp.2017.36.9.723

Braver, S. L., \& Lamb, M. E. (2013). Marital Dissolution. In Handbook of Marriage and the Family (pp. 487-516). Springer US. https://doi.org/10.1007/978-1-4614-3987-5_21

Brooks, S. K., Dunn, R., Sage, C. A. M., Amlôt, R., Greenberg, N., \& Rubin, G. J. (2015). Risk and resilience factors affecting the psychological wellbeing of individuals deployed in humanitarian relief roles after a disaster. Journal of Mental Health, 24(6), 385-413. https://doi.org/10.3109/09638237.2015.1057334

Calhoun, L. G., Cann, A., \& Tedeschi, R. G. (2012). The Posttraumatic Growth Model: Sociocultural Considerations. In Posttraumatic Growth and Culturally Competent Practice (pp. 1-14). John Wiley \& Sons, Inc. https://doi.org/10.1002/9781118270028.ch1

Calhoun, L. G., \& Tedeschi, R. G. (2006). The Foundations of Posttraumatic Growth: An Expanded Framework. In L. G. Calhoun \& R. G. Tedeschi (Eds.), Handbook of Posttraumatic Growth: Research and Practice (pp. 3-23). Lawrence Erlbaum Associates Publishers.

Connor, K. M., \& Davidson, J. R. T. (2003). Development of a new resilience scale: The Connor-Davidson Resilience Scale (CD-RISC). Depression and Anxiety, 18(2), 76-82. https://doi.org/10.1002/da.10113

Davidson, R. D., O'Hara, K. L., \& Beck, C. J. A. (2014). Psychological and Biological Processes in Children Associated with High Conflict Parental Divorce. Juvenile and Family Court Journal, 65(1), 29-44. https://doi.org/10.1111/jfcj.12015

Dekel, S., Mandl, C., \& Solomon, Z. (2011). Shared and unique predictors of posttraumatic growth and distress. Journal of Clinical Psychology, 67(3), 241-252. https://doi.org/10.1002/jclp.20747

Du, H., Li, X., Chi, P., Zhao, J., \& Zhao, G. (2017). Meaning in life, resilience, and psychological well-being among children affected by parental HIV. AIDS Care, 29(11), 1410-1416. https://doi.org/10.1080/09540121.2017.1307923

Greup, S. R., Kaal, S. E. J., Jansen, R., Manten-Horst, E., Thong, M. S. Y., van der Graaf, W. T. A., Prins, J. B., \& Husson, O. (2018). Post-Traumatic Growth and Resilience in Adolescent and Young Adult Cancer Patients: An Overview. Journal of Adolescent and Young Adult Oncology, 7(1), 1-14. https://doi.org/10.1089/jayao.2017.0040 
Harding, T., Lopez, V., \& Klainin-Yobas, P. (2019). Predictors of Psychological WellBeing among Higher Education Students. Psychology, 10(04), 578-594. https://doi.org/10.4236/psych.2019.104037

Harrington, R., \& Loffredo, D. A. (2010). Insight, Rumination, and Self-Reflection as Predictors of Well-Being. The Journal of Psychology, 145(1), 39-57. https://doi.org/10.1080/00223980.2010.528072

Hayes, A. F., \& Rockwood, N. J. (2017). Regression-based statistical mediation and moderation analysis in clinical research: Observations, recommendations, and implementation. Behaviour Research and Therapy, 98, 39-57. https://doi.org/10.1016/j.brat.2016.11.001

Hefferon, K., \& Boniwell, I. (2011). Positive Psychology (1st ed.). McGraw Hill.

Hornor, G. (2015). Childhood Trauma Exposure and Toxic Stress: What the PNP Needs to Know. Journal of Pediatric Health Care, 29(2), 191-198. https://doi.org/10.1016/j.pedhc.2014.09.006

Hu, J., Feng, B., Zhu, Y., Wang, W., Xie, J., \& Zheng, X. (2017). Gender Differences in PTSD: Susceptibility and Resilience. In Gender Differences in Different Contexts. InTech. https://doi.org/10.5772/65287

Kira, I., Lewandowski, L., Somers, C. L., Yoon, J. S., \& Chiodo, L. (2012). The effects of trauma types, cumulative trauma, and PTSD on IQ in two highly traumatized adolescent groups. Psychological Trauma: Theory, Research, Practice, and Policy, 4(1), 128-139. https://doi.org/10.1037/a0022121

Leme, V. B. R., Del Prette, Z. A. P., \& Coimbra, S. (2015). Social Skills, Social Support and Well-Being in Adolescents of Different Family Configurations. Paidéia (Ribeirão Preto), 25(60), 9-17. https://doi.org/10.1590/1982-43272560201503

Mahdi, H. K., Prihadi, K., \& Hashim, S. (2014). Posttraumatic Growth and Resilience after A Prolonged War: A Study in Baghdad, Iraq. International Journal of Evaluation and Research in Education (IJERE), 3(3). https://doi.org/10.11591/ijere.v3i3.6316

Meyerson, D. A., Grant, K. E., Carter, J. S., \& Kilmer, R. P. (2011). Posttraumatic growth among children and adolescents: A systematic review. Clinical Psychology Review, 31(6), 949-964. https://doi.org/10.1016/j.cpr.2011.06.003

Monks, F. J., Knoers, A. M. P., \& Hadinoto, S. rahayu. (2014). Psikologi Perkembangan: Pengantar dalam Berbagai Bagiannya (3rd ed.). Gadjah Mada University Press.

O'Rourke, J. J. F., Tallman, B. A., \& Altmaier, E. M. (2008). Measuring post-traumatic changes in spirituality/religiosity. Mental Health, Religion $\mathcal{E}$ Culture, 11(7), 719-728. https://doi.org/10.1080/13674670801993336

Park, C. L., Chmielewski, J., \& Blank, T. O. (2010). Post-traumatic growth: finding positive meaning in cancer survivorship moderates the impact of intrusive thoughts on adjustment in younger adults. Psycho-Oncology, 19(11), 1139-1147. 
https://doi.org/10.1002/pon.1680

Pedoman Umum Perlindungan Anak Penanganan COVID-19. (2020).

https://www.kemenpppa.go.id/lib/uploads/slider/62d2e-pedoman-umumperlindungan-anak-penanganan-covid-19.pdf

Perceraian di Semarang Naik 3 Kali Lipat Selama Wabah Corona. (2020, June 24). CNN Indonesia.

https://www.cnnindonesia.com/nasional/20200624103600-20-

516800/perceraian-di-semarang-naik-3-kali-lipat-selama-wabah-corona

Potter, D. (2010). Psychosocial Well-Being and the Relationship Between Divorce and Children's Academic Achievement. Journal of Marriage and Family, 72(4), 933-946. https://doi.org/10.1111/j.1741-3737.2010.00740.x

Ramadhani, T., Djuanedi, \& Sismiati, A. (2016). Kesejahteraan Psikologis (Psychological Well-Being) Siswa yang Orangtuanya Bercerai. Jurnal Bimbingan Konseling, 5(1), 108-115.

Richardson, G. E. (2002). The metatheory of resilience and resiliency. Journal of Clinical Psychology, 58(3), 307-321. https://doi.org/10.1002/jclp.10020

Rizaty, M. A. (2021). Angka Perceraian di Jawa Tengah Tertinggi Nasional pada 2020. Databoks. https://databoks.katadata.co.id/datapublish/2021/05/16/angkaperceraian-di-jawa-tengah-tertinggi-nasional-pada-2020

Ruini, C., Vescovelli, F., \& Albieri, E. (2013). Post-traumatic Growth in Breast Cancer Survivors: New Insights into its Relationships with Well-Being and Distress. Journal of Clinical Psychology in Medical Settings, 20(3), 383-391. https://doi.org/10.1007/s10880-012-9340-1

Ryff, C., Almeida, D. M., Ayanian, J., Carr, D. S., Cleary, P. D., Coe, C., Davidson, R., Krueger, R. F., Lachman, M. E., Marks, N. F., Mroczek, D. K., Seeman, T., Seltzer, M. M., Singer, B. H., Sloan, R. P., Tun, P. A., Weinstein, M., \& Williams, D. (2017). Midlife in the United States (MIDUS 2), 2004-2006. Inter-university Consortium for Political and Social Research [distributor]. https://doi.org/10.3886/ICPSR04652.v7

Ryff, C. D. (1989). Happiness is everything, or is it? Explorations on the meaning of psychological well-being. Journal of Personality and Social Psychology, 57(6), 10691081. https://doi.org/10.1037/0022-3514.57.6.1069

Ryff, C. D. (2014). Psychological Well-Being Revisited: Advances in the Science and Practice of Eudaimonia. Psychotherapy and Psychosomatics, 83(1), 10-28. https://doi.org/10.1159/000353263

Ryff, C. D. (2017). Eudaimonic well-being, inequality, and health: Recent findings and future directions. International Review of Economics, 64(2), 159-178. https://doi.org/10.1007/s12232-017-0277-4

S Pappa, V. (2013). Relationships between Parents' Marital Status and the Psychological Wellbeing of Adolescents in Greece. Journal of Psychology \& Psychotherapy, 03(02). https://doi.org/10.4172/2161-0487.1000110 


\section{WIJAYA, WIDYORINI, PRIMASTURI, \& DOMINGUEZ}

Santrock, J. W. (2011). Remaja (11th ed.). Erlangga.

Savitri, W. C., \& Listiyandini, R. A. (2017). Mindfulness dan Kesejahteraan Psikologis pada Remaja. Psikohumaniora: Jurnal Penelitian Psikologi, 2(1), 43. https://doi.org/10.21580/pjpp.v2i1.1323

Schaan, V. K., Schulz, A., Schächinger, H., \& Vögele, C. (2019). Parental divorce is associated with an increased risk to developmental disorders in women. Journal of Affective Disorders, 257, 91-99. https://doi.org/10.1016/j.jad.2019.06.071

Sun, J., \& Stewart, D. (2007). Age and Gender Effects on Resilience in Children and Adolescents. International Journal of Mental Health Promotion, 9(4), 16-25. https://doi.org/10.1080/14623730.2007.9721845

Tavernier, R., \& Willoughby, T. (2012). Adolescent turning points: The association between meaning-making and psychological well-being. Developmental Psychology, 48(4), 1058-1068. https://doi.org/10.1037/a0026326

Tedeschi, R. G., \& Calhoun, L. G. (1996). The posttraumatic growth inventory: Measuring the positive legacy of trauma. Journal of Traumatic Stress, 9(3), 455-471. https://doi.org/10.1002/jts.2490090305

Tedeschi, R. G., \& Calhoun, L. G. (2004). TARGET ARTICLE: "Posttraumatic Growth: Conceptual Foundations and Empirical Evidence." Psychological Inquiry, 15(1), 118. https://doi.org/10.1207/s15327965pli1501_01

Visani, D., Albieri, E., Offidani, E., Ottolini, F., Tomba, E., \& Ruini, C. (2011). Gender Differences in Psychological Well-Being and Distress During Adolescence. In The Human Pursuit of Well-Being (pp. 65-70). Springer Netherlands. https://doi.org/10.1007/978-94-007-1375-8_6

Vishnevsky, T., Cann, A., Calhoun, L. G., Tedeschi, R. G., \& Demakis, G. J. (2010). Gender Differences in Self-Reported Posttraumatic Growth: A Meta-Analysis. Psychology of Women Quarterly, 34(1), 110-120. https://doi.org/10.1111/j.14716402.2009.01546.x

Waterman, A. S., Schwartz, S. J., Zamboanga, B. L., Ravert, R. D., Williams, M. K., Bede Agocha, V., Yeong Kim, S., \& Brent Donnellan, M. (2010). The Questionnaire for Eudaimonic Well-Being: Psychometric properties, demographic comparisons, and evidence of validity. The Journal of Positive Psychology, 5(1), 41-61. https://doi.org/10.1080/17439760903435208

Yusuf, Y. (2020, September 15). Perceraian menumpuk Selama Covid-19, Terbanyak di Jawa Barat, Surabaya, dan Semarang. INews. https://www.inews.id/news/nasional/perceraian-menumpuk-selama-covid-19terbanyak-di-jawa-barat-subaya-dan-semarang 